\title{
Influence of calcium additions on the compressive strength and microstructure of alkali-activated ceramic sanitary-ware
}

\author{
L. Reig ${ }^{1}$, L. Soriano ${ }^{2}$, M.M. Tashima ${ }^{3}$, M.V. Borrachero², J. Monzó ${ }^{2}$, J.Payá, ${ }^{2 *}$ \\ ${ }^{1}$ EMC - Department of Mechanical Engineering and Construction, UniversitatJaume I, Castelló \\ de la Plana, Spain. \\ ${ }^{2}$ ICITECH - Instituto de Ciencia y Tecnología del Hormigón, Grupo de Investigación en Química \\ de los Materiales (GIQUIMA) UniversitatPolitècnica de València, Valencia, Spain. \\ ${ }^{3}$ Universidade Estadual Paulista (UNESP), Faculdade de Engenharia, Ilha Solteira. MAC - \\ Grupo de Pesquisa em Materiais Alternativos de Construção. São Paulo, Brazil.
}

* Corresponding author: jjpaya@cst.upv.es; Tel.: +34 963877564

E-mail addresses: Ireig@uji.es; lousomar@gmail.com; maumitta@hotmail.com; vborrachero@cst.upv.es; jmmonzo@cst.upv.es;ijpaya@cst.upv.es

\section{ABSTRACT}

The ceramic sanitary-ware market generates large amounts of waste, both during the production process and due to construction and demolition practices. In this paper, the effect of different amounts and calcium sources (calcium hydroxide $\mathrm{Ca}(\mathrm{OH})_{2}$, calcium aluminate cement CAC, Portland cement PC) on the alkaline activation of ceramic sanitary-ware waste (CSW) was assessed. Blended samples were activated with $\mathrm{NaOH}$ and sodium silicate solutions and cured for 3 and 7 days at $65^{\circ} \mathrm{C}$. The maximum amount of calcium source-type added to the system varied according to its influence on the compactability of the mortars.CSW was physicochemically characterized and the compressive strength development of activated samples was assessed on the mortars. The nature of the reaction products was analyzed in pastes, by X-ray diffraction, thermogravimetric analysis, infrared spectroscopy and microscopic studies. The results show a great positive influence with the addition of moderate amounts of $\mathrm{Ca}(\mathrm{OH})_{2}, \mathrm{PC}$ and CAC on the mechanical properties. Among the typical hydrates usually observed in plain 
water-hydrated PC or CAC, only $\mathrm{AH}_{3}$ and a small amount of $\mathrm{C}_{3} \mathrm{AH}_{6}$ were identified in the alkaliactivated CSW/CAC blended pastes, which indicates that Al and Ca from PC, CAC and $\mathrm{Ca}(\mathrm{OH})_{2}$ are taken up in the newly-formed $(\mathrm{N}, \mathrm{C})-\mathrm{A}-\mathrm{S}-\mathrm{H}$ or C-A-S-H gels.

Keywords: Alkali activation, cements, geopolymers, mechanical properties, microstructure 


\section{INTRODUCTION}

Portland cement was a key material during the Industrial Revolution and allowed great technological advances in the history of humanity. However, concerns about the natural resources consumed and the $\mathrm{CO}_{2}$ emitted during its production have prompted the scientific community and cement industry to seek more sustainable alternative binders. Among them, alkali-activated cements are being increasingly investigated, due to the lower energy cost and environmental impact. These binders allow reduced $\mathrm{CO}_{2}$ emissions and reuse of the industrial by-products, which contributes to minimizing the surfacerequired to dispose the waste and the exploitation of non-renewable raw materials ${ }^{1,2}$.

Although different aluminosilicate waste materials have been successfully used as a precursor to develop alkali-activated cements ${ }^{3}$, certain requirements must be met for the residue to be activated, such as high solubility in the basic medium and high availability of $\mathrm{Al}_{2} \mathrm{O}_{3}$ and $\mathrm{SiO}_{2}$ in the precursor ${ }^{4}$.The durability, hardness and high resistance to biological, chemical and physical degradation forces of ceramic sanitary-ware waste products (i.e. washbasins, lavatories, bidets...) give rise to serious environmental problems when dumping this ceramic waste in landfills, mainly motivated by dust pollution and the large areas of land which it occupies. An advantage of this ceramic waste, which facilitates its reuse and valorization, is that the products can be easily separated from dumps, since they are not attached to gypsum, cement or other binding materials. Given all the above-mentioned particularities, and by considering the prolonged period of biodegradation of a residue such as ceramic sanitary-ware (up to 4000 years $)^{5}$, exploring its potential use and valorization as a precursor to produce new alternative low $\mathrm{CO}_{2}$ binders by alkaline activation remains an attractive and highly interesting option.

Ceramic sanitary-ware waste (CSW) is not only generated during the refurbishment of buildings, but also due to the rejection of products during the production process, mainly due to breakage, deformed shapes or minor defects, which usually occur when firing the pieces, and affect the physico-chemical and aesthetic properties of the final product. According to data reported in Baraldiet al. ${ }^{6}$, world sanitary-ware production is estimated to have grown by $61.3 \%$ in a decade, 
rising from 216.6 to 349.3 million pieces produced in the years 2004 and 2014, respectively. Previous research focused on the reutilization of CSW as a raw material in the cement and concrete industry. While authors such as Medina et al. ${ }^{7,8}$ and Guerra et al. ${ }^{9}$ successfully replaced natural coarse aggregates with CSW in concrete production, Pacheco-Torgal and Jalali ${ }^{10}$ and Alves et al. ${ }^{11}$ investigated its use to replace natural fine aggregates. Moreover, its reutilization as a pozzolanic admixture was explored by Medina et al. ${ }^{12}$ and Reig et al. ${ }^{13}$, who replaced percentages of cement with ceramic waste within the $10-20 \%$ and $15-25 \%$ ranges, respectively. However, the use of ceramic sanitary-ware waste as a precursor to obtain binders by the alkali-activation process is a new line of research barely explored to date.

Preliminary studies on the alkali-activation of ceramic sanitary-ware waste were successfully performed by Reig et al. ${ }^{13,14}$, who investigated the optimum $\mathrm{NaOH} /$ sodium silicate mix proportions and the influence of $\mathrm{Ca}(\mathrm{OH})_{2}$ additions on the fresh behavior, mechanical strength and microstructure of the designed binders. The authors concluded that mortars activated by means of solutions with $7.28 \mathrm{~mol} \mathrm{~kg}^{-1}$ of $\mathrm{SiO}_{2}$ and $7.5 \mathrm{~mol} \mathrm{~kg}^{-1}$ of sodium $\left(\mathrm{Na}^{+}\right)$, blended with 4.5 wt $\%$ of $\mathrm{Ca}(\mathrm{OH})_{2}$, exhibited the best workability with good compressive strength results (21 and $27.5 \mathrm{MPa}$ after 3 and 7 curing days at $65^{\circ} \mathrm{C}$, respectively). They also observed that the addition of $\mathrm{Ca}(\mathrm{OH})_{2}$ proved essential for the alkali-activation process, which prompts a great interest in further analyses on the influence of various calcium sources on the microstructure and mechanical properties of CSW alkali-activated mortars. In this regard, previous studies have focused on this issue and analyzed the influence of additions such as calcium aluminate cement $(\mathrm{CAC})^{4,15,16}$, Portland cement $(\mathrm{PC})^{4,17}$ or $\mathrm{Ca}(\mathrm{OH})_{2}{ }^{18,19}$ on the reactivity and properties of alkaliactivated blended systems with different precursors. They generally concluded that these admixtures enhance the reactivity of the system and contribute to the mechanical strength development of the samples. Specifically, the influence of $\mathrm{Ca}(\mathrm{OH})_{2}$ on alkali-activated ceramic materials was investigated by Reig et al. ${ }^{18,19}$. Although porcelain stoneware tile waste was successfully activated and mortars with compressive strengths close to $30 \mathrm{MPa}$ (7 days, $65^{\circ} \mathrm{C}$ ) were obtained ${ }^{18}$, no activation took place in the absence of calcium hydroxide, and rapid setting occurred when $5 \%$ of the residue was replaced with this calcium source. Further research studied the influence of the alkali activator concentration and calcium dosage on the activation 
process of porcelain stoneware tiles ${ }^{19}$. It was concluded that mortars prepared with a constant calcium to sodium molar ratio $\left(\mathrm{M}_{\mathrm{Ca}}\right)$ presented an equal setting time. Also, when both the $\mathrm{SiO}_{2}$ concentration and $\mathrm{M}_{\mathrm{Ca}}$ were constant, the mortars exhibited a linear increase of the compressive strength with the sodium concentration.

According to the review by Shi et al. ${ }^{4}$, CAC additions have been observed to improve the reactivity and mechanical properties of alkali-activated binders. Results were confirmed in Reig et al. ${ }^{15}$, where CAC proved to accelerate the activation process of red clay brick waste, increasing the compressive strength by $68.6 \%$ and $165.7 \%$ in the mortars that contained 20 wt $\%$ and $40 \mathrm{wt} \% \mathrm{CAC}$ (cured for 7 days at $65^{\circ} \mathrm{C}$ ), respectively. Both studies agree that, in the systems that contained up to $20 \mathrm{wt} \%$ cement, the CAC hydration pattern differs from that usually observed in water, and the $\mathrm{Al}$ and $\mathrm{Ca}$ from $\mathrm{CAC}$ are taken up in the alkali-activated aluminosilicate gel formed, so that the typical CAC hydrates that appear during standard water hydration $\left(\mathrm{CAH}_{10}, \mathrm{C}_{2} \mathrm{AH}_{8}, \mathrm{C}_{3} \mathrm{AH}_{6}, \mathrm{AH}_{3}\right)$ were not identified in the alkali-activated samples. The hexagonal aluminates $\left(\mathrm{CAH}_{10}\right.$ and $\left.\mathrm{C}_{2} \mathrm{AH}_{8}\right)$ were not distinguished either in the studies by Arbi et al. ${ }^{16}$, where $20 \%$ CAC addition was used on alkali-activated blast furnace slag and diatomite (using $8 \mathrm{M} \mathrm{NaOH}$ solution), and Pastor et al. $^{20}$, who hydrated CAC with $8 \mathrm{M}$ and $12 \mathrm{M} \mathrm{NaOH}$ solutions. However, in both studies the cubic hydrate $\left(\mathrm{C}_{3} \mathrm{AH}_{6}\right)$ was formed from very early ages ( 2 days at room temperature).

Studies on alkali-activated Portland cement blended systems (hybrid alkaline cements) have also shown that Portland cement hydration differs from that usually observed in water, depending on the $\mathrm{pH}$ and the presence of soluble silica ${ }^{4}$. After analyzing the cementitious gels formed in 70\%FA-30\%PC hybrid cements hydrated with water and with $12.5 \mathrm{M} \mathrm{NaOH}$ and sodium silicate solutions, Garcia-Lodeiroet al. ${ }^{17}$ confirmed that the traditional products formed during water hydration diverge from that yielded during alkaline activation. This improved the mechanical properties of the activated hybrid cements when compared to the water-hydrated systems (both at 28 and 365 curing days), which was interpreted as an acceleration of the fly ash reaction. 
The work reported in this paper aims to investigate the influence of different sources and amounts of calcium on the mechanical properties and microstructure of alkali-activated ceramic sanitary-ware waste binders. This could open a new way of valorizing the residues from the sanitary-ware industry and demolition activity.

\section{EXPERIMENTAL PROCEDURE}

\subsection{Materials}

Ceramic sanitary-ware waste (CSW) pieces were crushed in a jaw crusher BB200 (Retsch) and then dry-milled in alumina medium (Gabrielli Mill-2 ball mill) for 25 minutes (90 balls of alumina, $450 \mathrm{~g}$ of waste) to obtain a milled material with a mean particle diameter, $d_{10}, d_{50}$ and $d_{90}$ of $23.9,1.7,15.8$ and $60.7 \mu \mathrm{m}$, respectively (determined through laser granulometry in a Mastersizer 2000, by Malvern Instruments).The morphology of thecrushed CSW and the milled CSW particles is shown in Fig. 1. As observed in Fig. 1a, the crushed CSW particles are composed of a white ceramic body with an external glaze covering, and both parts constitute the precursor to be activated. The milling process homogeneized the sample and the chemical composition of the ground material is the weighted average of both parts. Dense and irregularlyshaped particles were observed by scanning electron microscopy (SEM JEOL JSM-6300, Fig. $1 \mathrm{~b}$ and $1 \mathrm{c})$.
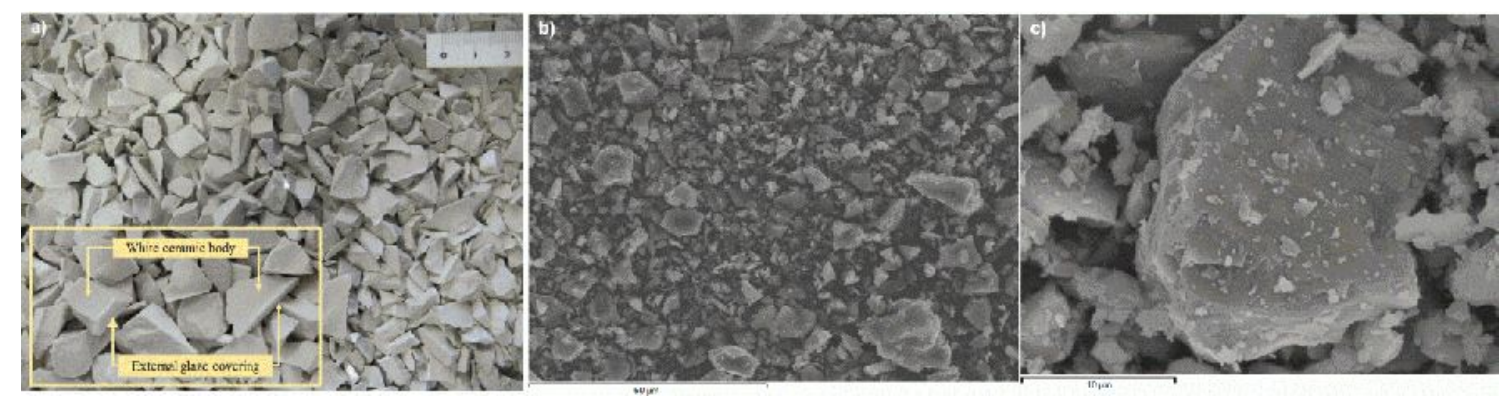

Fig. 1.Images of ceramic sanitary-ware waste: a) Crushed; b) Milled; c) Milled, magnification.

The chemical composition of CSW, determined by X-ray fluorescence (XRF) in a Philips Magix Pro spectrometer, is shown in Table 1.The residue is mainly composed of $\mathrm{SiO}_{2}$ and $\mathrm{Al}_{2} \mathrm{O}_{3}$ (the 
sum is $89.6 \mathrm{wt} \%)$ and contains a low percentage of $\mathrm{CaO}(1.2 \%)$. These values are close to those previously reported by Pacheco-Torgal and Jalali ${ }^{10}$, who also found the silica and alumina content close to $90 \mathrm{wt} \%$ for white paste sanitary-ware. The amorphous CSW content, determined according to specification UNE EN 196-2, was $45.76 \%$ (soluble fraction of the waste).

Table 1. Chemical composition of CSW (wt\%)

\begin{tabular}{ccccccccc}
\hline & $\mathrm{Al}_{2} \mathrm{O}_{3}$ & $\mathrm{SiO}_{2}$ & $\mathrm{CaO}$ & $\mathrm{Fe}_{2} \mathrm{O}_{3}$ & $\mathrm{~K}_{2} \mathrm{O}$ & $\mathrm{P}_{2} \mathrm{O}_{5}$ & Others & $\mathrm{LOI}$ \\
$\mathrm{CsW}$ & 23.6 & 66.0 & 1.2 & 1.3 & 2.9 & 0.5 & 1.4 & 0.3 \\
\hline
\end{tabular}

The mineralogical composition of CSW was determined by X-ray diffraction (XRD, Brucker AXS D8 Advance), from $10^{\circ}$ to $70^{\circ} 2 \theta$ degrees, with Cu Ka radiation at $40 \mathrm{kV}$ and $20 \mathrm{~mA}$. As plotted in Fig. 2, quartz (Q, SiO 2 , PDFcard331161) and mullite ( $\mathrm{M}, \mathrm{Al}_{6} \mathrm{Si}_{2} \mathrm{O}_{13}, \mathrm{PDF}$ card150776) were the major crystalline phases identified, and small amounts of the potassium feldspar microcline $(\mathrm{m}$, $\mathrm{KAISi}_{3} \mathrm{O}_{8}, \mathrm{PDF}$ card190926) were also distinguished. A deviation from the baseline was observed within the $15^{\circ}$ to $30^{\circ} 2 \theta$ degrees range, which denotes considerable amounts of amorphous phases in the CSW waste material.

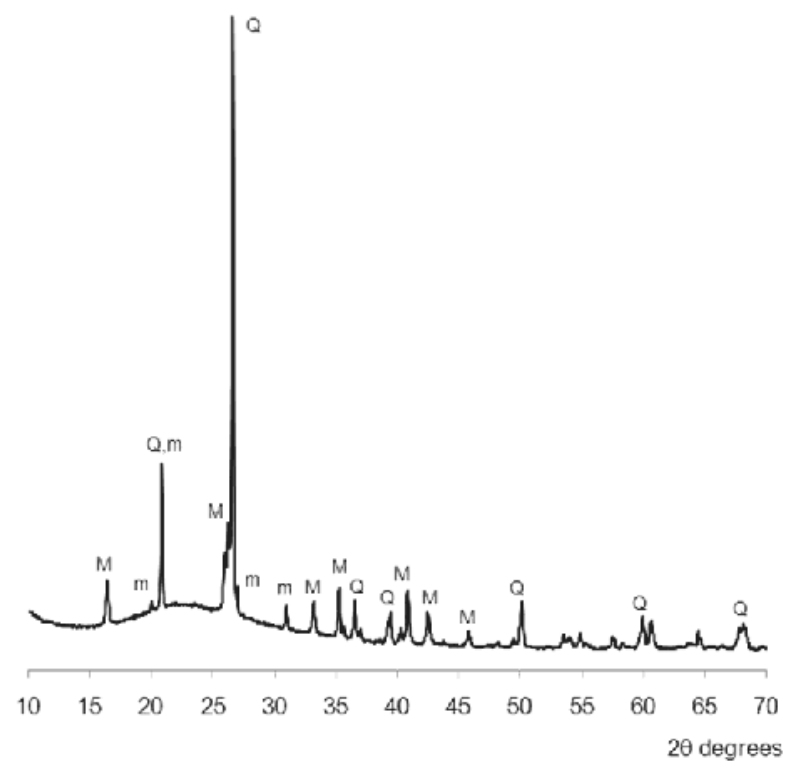

Fig. 2.XRD pattern for the raw CSW material.Q: Quartz $\left(\mathrm{SiO}_{2}\right)$; $\mathrm{M}$ :mullite $\left(\mathrm{M}, \mathrm{Al}_{6} \mathrm{Si}_{2} \mathrm{O}_{13}\right)$; microcline $\left(\mathrm{m}, \mathrm{KAISi}_{3} \mathrm{O}_{8}\right)$. 
$\mathrm{Ca}(\mathrm{OH})_{2}$ (purity higher than 96\%), calcium aluminate cement (CAC, composed mainly of 37.1 wt. $\% \mathrm{Al}_{2} \mathrm{O}_{3}, 35.4$ wt.\% $\mathrm{CaO}, 15.6$ wt.\% $\mathrm{Fe}_{2} \mathrm{O}_{3}$ and 4.9 wt. $\% \mathrm{SiO}_{2}{ }^{15}$ and provided by CementosMolins S.A., Barcelona, Spain) and Portland cement (PC, CEM I 52.5R, Lafarge, Puerto de Sagunto, Spain) were used as calcium sources. Siliceous sand (4.36 modulus fineness and maximum particle diameter of $2 \mathrm{~mm}$ ) was used for mortar preparation. Sodium hydroxide pellets (98\% purity, Panreac) and sodium silicate (Merck, $28 \% \mathrm{SiO}_{2}, 8 \% \mathrm{Na}_{2} \mathrm{O}, 64 \%$ $\mathrm{H}_{2} \mathrm{O}$ ) were used for the preparation of alkaline activating solutions.

\subsection{Samples preparation}

Pastes and mortars were produced according to the process previously described in Reig et al. $^{15,21}$. Mix proportions were adopted from previous studies ${ }^{13,14}$, where $\mathrm{NaOH}$, sodium silicate and $\mathrm{Ca}(\mathrm{OH})_{2}$ contents were optimized for thealkali-activated ceramic sanitary-ware waste binders. These studies ${ }^{13,14}$ revealed that addition of calcium was essential for the alkaliactivation of CSW to occur, and that the mix proportions strongly influenced the setting time and workability of the developed mortars. The best results were obtained in the samples prepared with a water to binder ratio of $0.40, \mathrm{Na}^{+}$and $\mathrm{SiO}_{2}$ concentrations of 7.5 and $7.28 \mathrm{~mol} \mathrm{~kg}^{-1}$, respectively, and 4.5 wt.\% of $\mathrm{Ca}(\mathrm{OH})_{2}$. The $\mathrm{SiO}_{2} / \mathrm{Na}_{2} \mathrm{O}$ mass ratio and the modulus of sodium $\left(\mathrm{M}_{\mathrm{Na}}\right)$ of this system were 1.88 and 0.236 , respectively. As defined in ${ }^{13}, \mathrm{M}_{\mathrm{Na}}$ is the ratio between the moles of sodium $\mathrm{Na}^{+}$in the activating solution and the amount of $\mathrm{SiO}_{2}$ and $\mathrm{Al}_{2} \mathrm{O}_{3}$ in the precursor CSW.This sample was used as the reference throughout the study.

All samples were prepared with a water to binder ratio of 0.40 , and with $\mathrm{Na}^{+}$and $\mathrm{SiO}_{2}$ concentrations in the activating solution of 7.5 and $7.28 \mathrm{~mol} \mathrm{~kg}^{-1}$, respectively. The binder was composed of CSW and its partial replacement with different calciumsourceswere: $\mathrm{Ca}(\mathrm{OH})_{2}$, in $4.5 \%, 6 \%$ and $8 \%$; PC, in $5 \%, 10 \%$ and $15 \%$; CAC, in $5 \%, 10 \%, 15 \%, 20 \%, 30 \%, 40 \%, 50 \%$ and $100 \%$. The percentages used for eachcalcium source were chosen depending on the feasibility of compacting the fresh material into the molds (by vibration). Maximum amounts of 8 wt $\%$ and 15 wt. \% were used for $\mathrm{Ca}(\mathrm{OH})_{2}$ and $\mathrm{PC}$, respectively, since mortars with further additions presented dry consistency and could not be compacted. The good workability of the 
mortars that contained CAC allowed to use $50 \mathrm{wt} . \%$, and even $100 \mathrm{wt} . \%$ CAC. These samples with such high CAC contents were prepared only for comparison purposes.A binder (precursor) to sand ratio of 1:3 was used in all the prepared mortars. Pastes and mortars were cured in a thermostatically controlled bath at $65^{\circ} \mathrm{C}$ and $95 \%$ relative humidity(floating in a water bath inside a sealed box) for 3 and 7 days.

\subsection{Pastes and mortars characterization}

The compressive strength of alkali-activated CSW blended mortars was tested according to UNE EN 196-1:2005 standard, after 3 and 7 curing days at $65^{\circ} \mathrm{C}$. The influence of the different sources and amounts of calcium on the microstructure developed was investigated in pastes cured at $65 \stackrel{\circ}{\circ}$ for 7 days. Thermogravimetric analyses were performed in a TGA-850 MettlerToledo thermobalance, at a heating rate of $10^{\circ} \mathrm{C} \mathrm{min}^{-1}$ from $35^{\circ} \mathrm{C}$ to $600^{\circ} \mathrm{C}$, under $\mathrm{N}_{2}$ atmosphere and using sealed pin-holed aluminum crucibles. The Fourier-transformed infrared spectroscopy (FTIR, Bruker Tensor 27 Platinum ATR spectrometer, 32-second acquisition time) data were collected in the transmittance mode, from 4000 to $400 \mathrm{~cm}^{-1}$ and X-ray diffraction tests were run in a Brucker AXS D8 Advance, under the conditions previously described in section 2.1. Scanning electron microscopy images of fractured surfaces of the pastes were obtained using a SEM-EDX JEOL JSM-6300 microscope, equipped with an energy dispersive X-ray for the microanalysis.

\section{RESULTS AND DISCUSSION}

\subsection{Mechanical strength}

The compressive strength results of the mortars with different percentages of calcium additions, cured at $65^{\circ} \mathrm{C}$ for 3 and 7 days, are plotted in Fig. 3. The substitution of CSW with the different calcium sources $\left(\mathrm{Ca}(\mathrm{OH})_{2}, \mathrm{PC}\right.$ and $\left.\mathrm{CAC}\right)$, according to the experimental layout described, generally improves the mechanical properties of the alkali-activated mortars. Although $\mathrm{Ca}(\mathrm{OH})_{2}$ provides the best mechanical properties when used in low proportions (up to $6 \mathrm{wt} \%$ ), the 
maximum quantity that can be used is relatively small, since mortars with more than $8 \mathrm{wt} \%$ $\mathrm{Ca}(\mathrm{OH})_{2}$ cannot be compacted due to their dry consistency. The strength of $\mathrm{Ca}(\mathrm{OH})_{2}$ mortars significantly improved when increasing the percentage of substitution from 4.5 to $6 \mathrm{wt} \%$ (27.29 and $40.06 \mathrm{MPa}$ respectively, at 7 curing days). However, similar properties were obtained with further $\mathrm{Ca}(\mathrm{OH})_{2}$ addition (8\%), which is attributed to the lower compactability of this mortar. These results are close to those previously reported in Reig et al. ${ }^{19}$ for alkali-activated porcelain stoneware tiles waste, where up to $36 \mathrm{MPa}$ were obtained in mortar samples blended with $5 \%$ $\mathrm{Ca}(\mathrm{OH})_{2}$ and activated with $12.5 \mathrm{~mol} . \mathrm{kg}^{-1}$ of $\mathrm{Na}^{+}$and $7.28 \mathrm{~mol} \mathrm{~kg}^{-1}$ of $\mathrm{SiO}_{2}$ solution, cured for 7 days at $65 \stackrel{\circ}{\circ}$.

Although production of $\mathrm{PC}$ or $\mathrm{CAC}$ emits $\mathrm{CO}_{2}$ to the atmosphere, consumesnatural resources and requires fuel burning to reach clinkering temperatures, the alkali-activated CSW mortars prepared with up to $15 \mathrm{wt} . \%$ cement (CAC or PC) significantly improved their mechanical properties. Since waste material CSW is being replaced with othersthat havea negative environmental impact, the smaller the amount of ceramic waste to be replaced with PC or CAC cement, the better.The obtained results confer a great practical interest to these cement additions since improvement in the mechanical properties achieved with relatively low cement contents (up to $15 \mathrm{wt} . \%$ ) provide benefits from an environmental point of view (less synthetic materials and natural resources are used) andallow the alkali-activated CSW structural elements to be used in shorter times. It was not possible to preparesamples with more than 15 wt\% PC (due to rapid setting and dry consistency), but the good workability and long setting time of the CAC mortars allowed mortars to be produced with $50 \mathrm{wt} \%$, and even $100 \mathrm{wt} \%$ CAC contents (both prepared only for comparison purposes). The mechanical properties of $5 \mathrm{wt} \%$ PC mortars were higher than those prepared with the same amount of CAC; however, the tendency reversed with 15 wt\% replacement (the strengths of the CAC mortars were higher than the PC ones), which is attributed to the better compactability observed when using CAC. The mortars prepared with 10 wt\% PC or CAC exhibited the best mechanical properties improvement with curing time (49.6\% and $44.73 \%$, respectively). In the study performed by Garcia Lodeiroet al. ${ }^{17}$, where $\mathrm{FA} / \mathrm{PC}$ blended pastes ( 30 wt\% $\mathrm{PC}$ ) were activated with $\mathrm{NaOH} / \mathrm{Na}_{2} \mathrm{SiO}_{3}$ solutions, 35 MPa was reported after 365 days at room temperature. Similarly, 33 MPa was reported in hybrid 
alkaline cements consisting of $60 \mathrm{wt} \%$ clinker and $40 \mathrm{wt} \%$ incinerator waste (blend of fly ash and bottom ash), activated with a mix of $\mathrm{CaSO}_{4}, \mathrm{Na}_{2} \mathrm{SO}_{4}$ and water, and cured for 28 days ${ }^{22}$. In our case, similar or better strengths were obtained, probably due to the higher curing temperature $\left(65^{\circ} \mathrm{C}\right)$ or to the improved reactivity of the CSW precursor. When compared with the mortars prepared with $\mathrm{Ca}(\mathrm{OH})_{2}$, the bettercompressive strength results are attributed to the possibility of using larger cement amounts, and to the fact that CAC or PC additions would not only provide calcium, but also other elements, mainly aluminum and silicon respectively.

The results exhibited by the alkali-activated CSW/CAC blended mortars differ from those previously reported by Fernández-Jiménez et al..$^{23}$ for alkali-activated metakaolin/CAC blended pastes prepared with $20 \% \mathrm{CAC}$, where strength values close to $13 \mathrm{MPa}$ were reported after 20 curing hours at $85^{\circ} \mathrm{C}$. The strength of the CSW/CAC mortars significantly improved with up to 20 wt\% CAC substitutions and generally decreased with further additions. This behavior could be attributed to the delay in the CAC hardening process previously observed by Pastor et al. ${ }^{20}$ when hydrating $\mathrm{CAC}$ with highly alkaline $\mathrm{NaOH}$ solutions. In our CSW-CAC activated system, and under the studied conditions, the interaction between $\mathrm{NaOH}$ in the activating solution and CAC particles increases with higher CAC contents which, consequently,retards the hydration of CAC. This behavior also differs from that previously observed for alkali-activated red clay brick waste and CAC blended systems ${ }^{15}$, where compressive strength values progressively increased with the addition of CAC (values close to $40,60,70$ and $92 \mathrm{MPa}$ in the mortars that contained $10,20,30$ and 40 wt $\%$ CAC, respectively, cured at $65{ }^{\circ} \mathrm{C}$ for 7 days). 


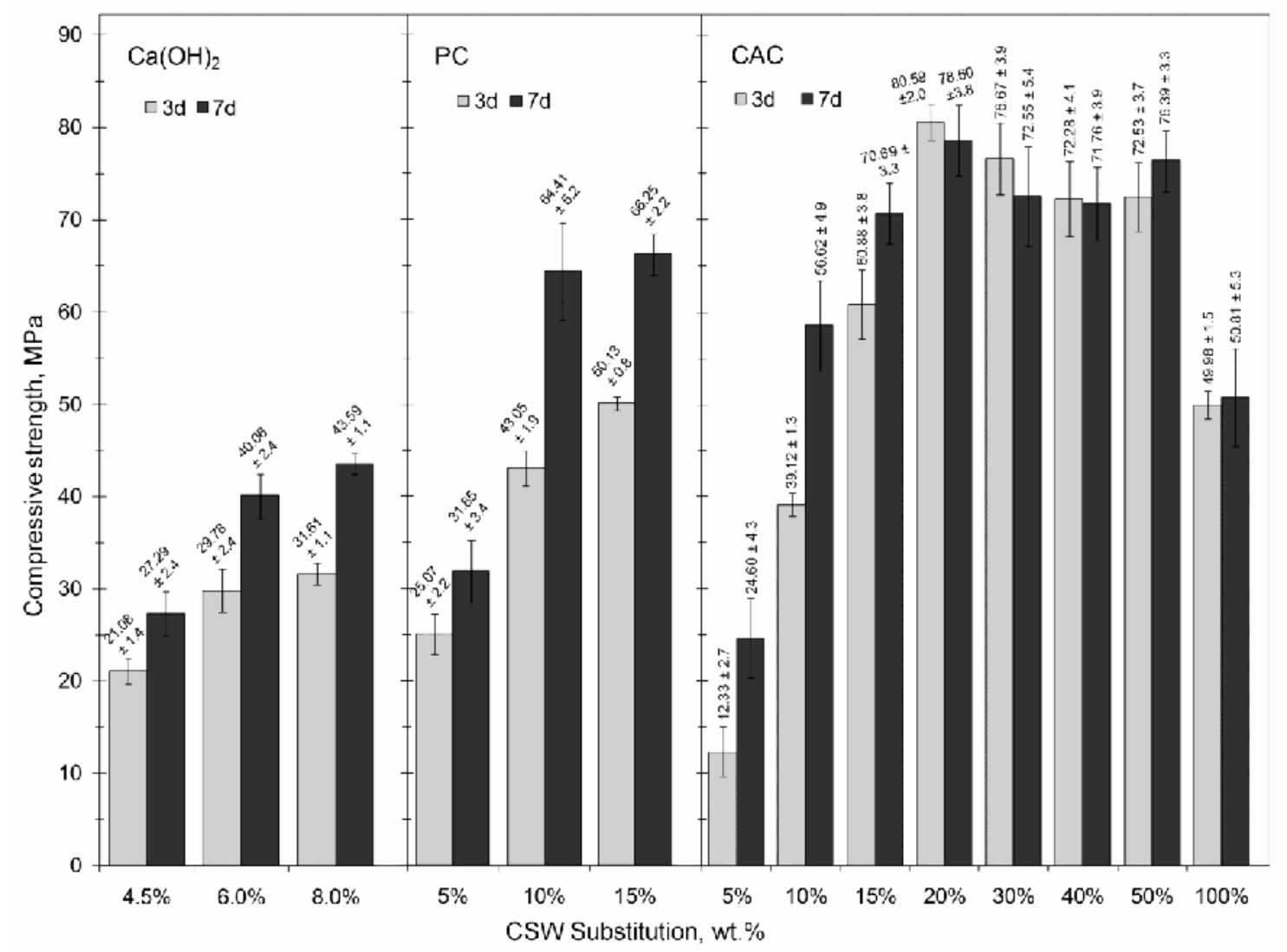

Fig. 3. Compressive strength of the alkali-activated CSW blended mortars developed with different calcium sources.

\subsection{X-ray diffraction (XRD)}

The XRD patterns for the selected alkali-activated pastes blended with different amounts of the calcium sources are presented in Fig. 4. The reference paste $\left(4.5 \mathrm{wt} . \% \mathrm{Ca}(\mathrm{OH})_{2}\right)$, those containing 8 wt. $\% \mathrm{Ca}(\mathrm{OH})_{2}$ and 15 wt.\% PC (maximum contents which providedgood workability), and those prepared with $10 \mathrm{wt} . \%$ of PC and 10 and $20 \mathrm{wt} . \%$ CAC (which resulted ingood mechanical properties with relatively low cement additions) were selected for the microstructural analyses. The diffractogram of the CSW raw material was also plotted for comparison purposes. Signals attributed to quartz (Q, $\mathrm{SiO}_{2}, \mathrm{PDF}$ card331161), mullite(M, $\left.\mathrm{Al}_{6} \mathrm{Si}_{2} \mathrm{O}_{13}, \mathrm{PDF} c a r d 150776\right)$ and microcline ( $\left.\mathrm{m}, \mathrm{KAISi}_{3} \mathrm{O}_{8}, \mathrm{PDFcard} 190926\right)$, previously identified in the precursor (Section 2.1), appeared in all the activated pastes, which denotes that these crystalline phases did notreact (or was at least a very limited reaction) during the activation process. As described in previous studies ${ }^{16,17}$, the slight displacement of the baseline, from 15- 
$30^{\circ} 2 \theta$ degrees in the ceramic waste raw material toward higher angles (20-35 $2 \theta$ degrees) in the alkali-activated blended samples, is attributed to the formation of the binding geopolymeric gel.

In agreement with the previous study by Reig et al. ${ }^{19}$, where porcelain stoneware tiles waste was activated in the presence of $\mathrm{Ca}(\mathrm{OH})_{2}$, no peaks attributed to $\mathrm{Ca}(\mathrm{OH})_{2}$ were clearly distinguished in the diffraction pattern, which indicates that it was consumed during the activation reactions. The signals attributed to the sodium carbonate decahydrate natron $(\mathrm{N}$, $\mathrm{Na}_{2} \mathrm{CO}_{3} 10 \mathrm{H}_{2} \mathrm{O}$, PDFcard150800) were identified in the $\mathrm{Ca}(\mathrm{OH})_{2}$ blended pastes, which is also in line with previously reported results ${ }^{19}$.

Although no peaks associated with the formation of new crystalline compounds were observed after the alkali-activation of CSW/PC blended pastes, signals arising due to larnite $\left(\beta-\mathrm{Ca}_{2} \mathrm{SiO}_{4}\right.$, PDFcard330302, usually referred to as belite in the cement industry) denote that PC was only partially consumed/hydrated after 7 days at $65^{\circ} \mathrm{C}$. Calcite $\left(\mathrm{C}, \mathrm{CaCO}_{3}, \mathrm{PDF}\right.$ card050586), which is attributed mainly to the presence of limestone filler in the Portland cement composition, was identified in the PC blended pastes. These findings are consistent with those previously reported by García-Lodeiroet al. ${ }^{17}$, where neither portlandite nor ettringite was distinguished in the alkali-activated FA/PC blended pastes that contained 30\% PC. As described by Shi et al. ${ }^{4}$, the absence of portlanditeconfirms that the PC hydration pathway followed in alkali-activated systems differs from that usually observed in water.

Similarly, none of the typical hydrates formed during standard water hydration of CAC (hexagonal aluminates $\mathrm{CAH}_{10}$ and $\mathrm{C}_{2} \mathrm{AH}_{8}$, or the cubic phase $\mathrm{C}_{3} \mathrm{AH}_{6}$ ) was clearly distinguished in the XRD diffraction patterns of the CSW/CAC blended pastes, which indicates that CAC did not undergo normal hydration in the samples developed in the present study.Although no calcium aluminate hydrateswereidentified, aluminum hydroxide (in the forms ofbayerite and gibbsite)was formed. In the paste that contained $10 \mathrm{wt} \% \mathrm{CAC}$, the signals attributed to gibbsite (G, $\left.\mathrm{Al}(\mathrm{OH})_{3}, \mathrm{PDF} c a r d 070324\right)$ and bayerite $\left(\mathrm{B}, \mathrm{Al}(\mathrm{OH})_{3}, \mathrm{PDF} c a r d 200011\right)$ were identified; however, in the sample that contained $20 \mathrm{wt} \% \mathrm{CAC}$, the zeolitic phases faujasite $(F$, 
$\mathrm{Na}_{2} \mathrm{Al}_{2} \mathrm{Si}_{4} \mathrm{O}_{12} 8 \mathrm{H}_{2} \mathrm{O}$, PDFcard391380) and zeolite $\mathrm{A}\left(\mathrm{A} ; \mathrm{Na}_{2} \mathrm{Al}_{2} \mathrm{Si}_{1.85} \mathrm{O}_{7.7} 5.1 \mathrm{H}_{2} \mathrm{O}\right.$,

PDFcard380241), together with the sodium carbonate hydrate natron $\left(\mathrm{N}, \mathrm{Na}_{2} \mathrm{CO}_{3} 10 \mathrm{H}_{2} \mathrm{O}\right.$, PDFcard150800) and small amounts of gibbsite, were distinguished. According to the obtained results, the typical conversion problems associated with water-hydrated CAC, in which the transformation of the hexagonal hydrates into the cubic ones leads to loss of strength and increased porosity ${ }^{15}$, are not expected in the alkali-activated CSW systems prepared with up to 20 wt. \% CAC and cured at $65{ }^{\circ} \mathrm{C}$. The XRD results are in line with those previously described in the review by Shi et al. ${ }^{4}$, where it was explained that, instead of the typical hexagonal or cubic CAC hydrates being formed, $\mathrm{Al}$ and $\mathrm{Ca}$ from CAC were taken up in the newly-formed gel, and (N,C)-A-S-H or C-A-S-H gelswere produced, depending on the reaction conditions and blend proportions. These results were corroborated by Reig et al. ${ }^{15}$ in alkali-activated red clay brick waste/CAC blended systems (RCBW/CAC), where none of the typical CAC hydrates $\left(\mathrm{CAH}_{10}\right.$, $\mathrm{C}_{2} \mathrm{AH}_{8}, \mathrm{AH}_{3}, \mathrm{C}_{3} \mathrm{AH}_{6}$ ) was clearly distinguished in the pastes that contained up to $20 \mathrm{wt} \% \mathrm{CAC}$ and alkali-activated with $\mathrm{NaOH}$ and sodium silicate solutions (cured at $20{ }^{\circ} \mathrm{C}$ and $65{ }^{\circ} \mathrm{C}$ ). Whereas the cubic phase katoite $\left(\mathrm{C}_{3} \mathrm{AH}_{6}\right)$ was formed only in the RCBW/CAC pastes blended with $30 \mathrm{wt} \%$ and $50 \mathrm{wt} \% \mathrm{CAC}$ and cured at $65^{\circ} \mathrm{C}$, bayerite was identified only in that which contained 50 wt\% CAC (also cured at $65^{\circ} \mathrm{C}$ ). Neither did the XRD pattern reveal the formation of hexagonal hydrates $\left(\mathrm{CAH}_{10}\right.$ and $\left.\mathrm{C}_{2} \mathrm{AH}_{8}\right)$ in the study by Pastor et al. ${ }^{20}$, where cubic hydrate $\mathrm{C}_{3} \mathrm{AH}_{6}$ and $\mathrm{AH}_{3}$ were distinguished instead in $\mathrm{NaOH}$-hydrated $\mathrm{CAC}$ samples. Similar results were reported by Arbi et al. ${ }^{16}$, who observed the formation of (N,C)-A-S-H gel, katoite $\left(\mathrm{C}_{3} \mathrm{AH}_{6}\right)$ and two carboaluminates, hydrotalcite and $\mathrm{C}_{4} \mathrm{AcH}_{11}$, in $20 \% \mathrm{CAC}-80 \%$ blast furnace slag (BFS) blends alkali-activated with $8 \mathrm{M} \mathrm{NaOH}$ solutions.

Zeolite-type crystalline phases, hydrated aluminosilicates typically originated from the newlyformed alkaline aluminosilicate gel in alkali-activated low calcium systems ${ }^{24}$, were only distinguished in the CSW paste that contained 20 wt $\%$ CAC. Fernandez-Jimenez et al. ${ }^{25}$, who alkali-activated CAC in the presence of soluble silica, observed that the reaction between the silica, and the aluminum and calcium provided by CAC, was favored under those highly alkaline solutions, which led to the formation of a $(\mathrm{C}, \mathrm{N}) \mathrm{ASH}$ gel thatcould crystallize into zeolitic phases.Although zeolitic compounds have not been generally distinguished in previous studies 
of alkali-activated blended systems, such as fly ash/PC ${ }^{17}$ or ceramic porcelain stoneware/ $\mathrm{Ca}(\mathrm{OH})_{2}{ }^{19}$, the zeolitic phase herschelite $\left(\mathrm{NaAlSi}_{2} \mathrm{O}_{6} 3 \mathrm{H}_{2} \mathrm{O}\right)$ has been identified only in the RCBW/CAC blended systemthat contained $10 \mathrm{wt} \% \mathrm{CAC}^{15}$.

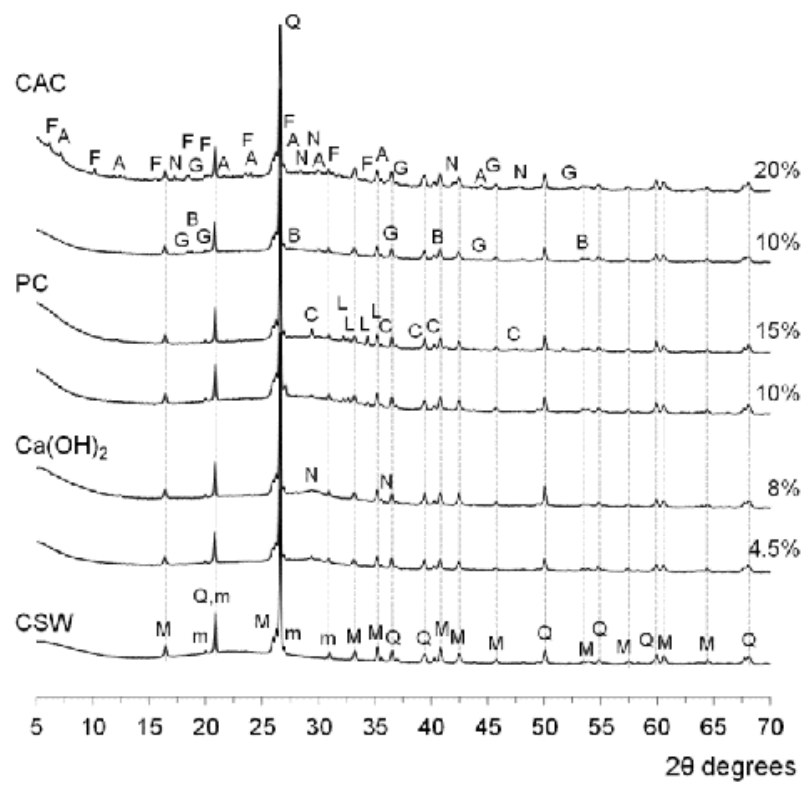

Fig. 4. XRD patterns for the CSW raw material and alkali-activated pastes prepared with different calcium sources and cured at $65^{\circ} \mathrm{C}$ for 7 days. $\mathrm{Q}$, quartz $\left(\mathrm{SiO}_{2}\right)$; $\mathrm{M}$, mullite $\left(\mathrm{Al}_{6} \mathrm{Si}_{2} \mathrm{O}_{13}\right)$; m, microcline $\left(\mathrm{KAISi}_{3} \mathrm{O}_{8}\right) ; \mathrm{C}$, calcite $\left(\mathrm{CaCO}_{3}\right) ; \mathrm{N}$, natron $\left(\mathrm{Na}_{2} \mathrm{CO}_{3} 10 \mathrm{H}_{2} \mathrm{O}\right)$; L, larnite $\left(\beta-\mathrm{Ca}_{2} \mathrm{SiO}_{4}\right)$; G, gibbsite $\left(\mathrm{Al}(\mathrm{OH})_{3}\right) ; \mathrm{B}$, bayerite $\left(\mathrm{Al}(\mathrm{OH})_{3}\right) ; \mathrm{F}$, faujasite $\mathrm{F}\left(\mathrm{Na}_{2} \mathrm{Al}_{2} \mathrm{Si}_{4} \mathrm{O}_{12} 8 \mathrm{H}_{2} \mathrm{O}\right)$; $\mathrm{A}$, zeolite $\mathrm{A}$ $\left(\mathrm{Na}_{2} \mathrm{Al}_{2} \mathrm{Si}_{1.85} \mathrm{O}_{7.7} 5.1 \mathrm{H}_{2} \mathrm{O}\right)$.

\subsection{Thermogravimetric analysis}

The differential thermogravimetric curves (DTG) of the alkali-activated CSW pastes, prepared with selected amounts of $\mathrm{Ca}(\mathrm{OH})_{2}, \mathrm{PC}$ and $\mathrm{CAC}$ and cured at $65^{\circ} \mathrm{C}$ for 7 days, are shown in Fig. 5. The results agree well with compressive strength evolution since total weight loss increased with calcium addition. All the curves exhibited a single broad band at $120-170 \stackrel{\circ}{ }$, which was attributed to the dehydration of the $\mathrm{NASH}$ or $(\mathrm{N}, \mathrm{C}) \mathrm{ASH}$ gels formed during the alkaliactivation process ${ }^{15,19}$. This band overlaps with those that resulted from the dehydration of different compounds, such as zeolitic phases $\left(60-160^{\circ} \mathrm{C}\right)^{26}$, alumina gel $\left(130^{\circ} \mathrm{C}\right)^{15}$, the typical hexagonal hydrates formed in water-hydrated $\mathrm{CAC}\left(\mathrm{CAH}_{10} \text { and } \mathrm{C}_{2} \mathrm{AH}_{8}, 150{ }^{\circ} \mathrm{C} \text { to } 180{ }^{\circ} \mathrm{C}\right)^{27}$, and 
the calcium silicate hydrates $(\mathrm{C}-\mathrm{S}-\mathrm{H})$ or ettringite $\left(\mathrm{A}_{\mathrm{ft}}\right)\left(100-180^{\circ} \mathrm{C}\right)^{28}$ that typically form in waterhydrated Portland cement systems. Thus it was not possible to clear distinguish these phases by TG tests. Similarly, it was not possible to confirm the presence of calcite and the hydrated sodium carbonate (natron), previously identified by XRD analyses in the alkali-activated CSW blended pastes, from the DTG curves since, according to Hidalgo et al. ${ }^{29}$, bands appear within the $625-875^{\circ} \mathrm{C}$ range.

No signals associated with the dehydroxylation of $\mathrm{Ca}(\mathrm{OH})_{2}\left(520-580^{\circ} \mathrm{C}\right)^{19,28}$ arose in any of the DTG curves, which confirms that $\mathrm{Ca}(\mathrm{OH})_{2}$ was consumed during the alkali-activation process, and that the Portland cement hydration pathway differed from that usually followed in waterhydrated systems (portlandite was not formed). The signals attributed to the dehydration of calcium aluminate hydrates and calcium aluminosilicate hydrates (CAH and CASH) (180$\left.240^{\circ} \mathrm{C}\right)^{28}$ were not distinguished in the PC blended pastes. On the contrary, small amounts of new phases were identified in the CSW/CAC samples. The band that arose within the 280-320 ${ }^{\circ} \mathrm{C}$ range in the curves of the CAC-activated pastes confirmed the presence of gibbsite and bayerite $\left(\mathrm{AH}_{3}\right)$, previously distinguished by $\mathrm{XRD}$ analyses. $\mathrm{A}$ band arose at $345^{\circ} \mathrm{C}$ and denoted the formation of small amounts of $\mathrm{C}_{3} \mathrm{AH}_{6}$, which were not clearly identified in the XRD pattern ${ }^{30}$. These results are in line with that previously reported by Pastor et al. ${ }^{20}$, who also distinguished katoite $\left(\mathrm{C}_{3} \mathrm{AH}_{6}\right)$ and aluminum hydroxide $\left(\mathrm{AH}_{3}\right)$ in alkali-activated $\mathrm{CAC}(8 \mathrm{M}$ and $12 \mathrm{M} \mathrm{NaOH}$ solutions). According to the previous studies by Fernández-Jiménez et al. ${ }^{25}$, who investigated the effect of sodium silicate on alkali-activated CAC, the presence of soluble silicon may modify the structure of katoite and lead to the formation of katoite-type phases $\left(C_{3} A S_{n} H_{m}\right)$.

The broadening and shift of the main band, attributed to the newly-formed gel, toward higher temperatures with more calcium contents denote a modification in the gel structure. As described in Reig et al. ${ }^{19}$, several studies suggest that calcium from $\mathrm{Ca}(\mathrm{OH})_{2}$ may act as a charge-balancing ion, and may lead to $(\mathrm{C}, \mathrm{N})-\mathrm{A}-\mathrm{S}-\mathrm{H}$ gels, or participate in the $\mathrm{C}-(\mathrm{A})-\mathrm{S}-\mathrm{H}$ gel formation, which mainly depends on the calcium concentration and $\mathrm{pH}$ of the system. In their review, Shi et al. ${ }^{4}$ also indicated that the hydration of CAC in alkali-activated systems differed from that which occurred when hydrated in water; so instead of forming the typical CAC 
hydrates, aluminum and calcium from the cement are taken up in the new geopolymeric gel formed. Similar conclusions have been reported by Garcia-Lodeiro et al. ${ }^{17}$ for $70 \%$ FA-30\%PC hybrid cements hydrated with water and $12.5 \mathrm{M} \mathrm{NaOH}$ and sodium silicate solutions, who concluded that the composition and microstructure of the gels formed in the presence of alkalis differed from the gels detected in the water-hydrated samples. In the alkali-activated system, a mix of C-S-H/N-A-S-H gels precipitates at early ages and, while the C-S-H gel evolves to C-A-S$\mathrm{H}$ in the presence of $\mathrm{Al}$, calcium interacts with $\mathrm{N}-\mathrm{A}-\mathrm{S}-\mathrm{H}$ to form $(\mathrm{N}, \mathrm{C})-\mathrm{A}-\mathrm{S}-\mathrm{H}$, which may even evolve to C-A-S-H if there is a suitable concentration of calcium ${ }^{17}$. Although these gels may coprecipitate, once formed the C-A-S-H gel remains, as it is the most thermodynamically stable form in mixes of aluminosilicate and calcium silicate gels.

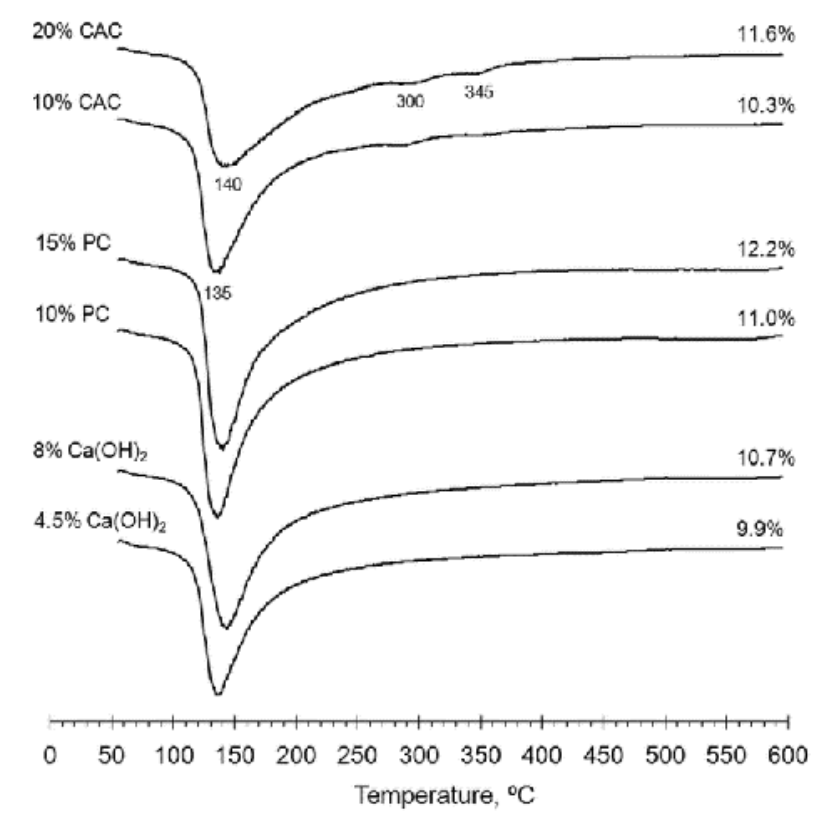

Fig. 5. Differential thermogravimetric curves for alkali-activated CSW pastes (total mass loss within the studied range is depicted to the right of each DTG curve).

\subsection{Infrared spectroscopy (FTIR)}

The FTIR curves of the alkali-activated CSW pastes, prepared with selected amounts of $\mathrm{Ca}(\mathrm{OH})_{2}, \mathrm{PC}$ and $\mathrm{CAC}$ and cured at $65^{\circ} \mathrm{C}$ for 7 days, are shown in Fig. 6 . The spectral pattern of the CSW is also included as a reference. Data were plotted from 400 to $2000 \mathrm{~cm}^{-1}$, since only 
very weak signals appeared within the $2000-400 \mathrm{~cm}^{-1}$ range. The signals that appeared at 453 $\mathrm{cm}^{-1}, 695 \mathrm{~cm}^{-1}, 775$ and 794 (double band) $\mathrm{cm}^{-1}, 1084 \mathrm{~cm}^{-1}$ and $1145 \mathrm{~cm}^{-124,31-33}$, were associated withquartz, which was also identified by XRD in the raw material and activated pastes (Section 3.2). The main band arising at $1185 \mathrm{~cm}^{-124}$, together with the low intensity bands at 570 and $734 \mathrm{~cm}^{-134}$, were attributedto mullite.

The signal that appeared at $453 \mathrm{~cm}^{-1}$, mainly attributed to quartz, shifted toward a lower wavenumber in the alkali-activated pastes because it overlapped the signals attributed to the deformation vibrations of the C-A-S-H and N-A-S-H gels ( $\delta \mathrm{Si}-\mathrm{O}-\mathrm{Si} / \delta \mathrm{Si}-\mathrm{O}-\mathrm{Al})^{35}$.The main band that resulted from the geopolymeric gel appeared to be centered at $995 \mathrm{~cm}^{-1}$ and wais attributed to the asymmetric stretching vibrations generated by the T-O-T bonds (T: Si or Al) in the newlyformed ge $\left.\right|^{25,36}$. Although no significant deviation was observed with the different sources and amounts of calcium, the signal was centered at a slightly lower wavenumber than those previously recorded for the alkali-activated porcelain stoneware tiles waste blended with $\mathrm{Ca}(\mathrm{OH})_{2}\left(1013-1020 \mathrm{~cm}^{-1}\right)^{19}$. As explained by Criadoet al. ${ }^{24}$, this indicates higher Al contents in the activated CSW gel since Si-O bonds are stronger than $\mathrm{Al}-\mathrm{O}$ bonds.

In agreement with the XRD results, no significant amounts of the typical CAC hydrates $\left(\mathrm{CAH}_{10}\right.$, $\mathrm{C}_{2} \mathrm{AH}_{8}$ and $\mathrm{C}_{3} \mathrm{AH}_{6}$ ), whose bands were found at $524 \mathrm{~cm}^{-1}$ and in the $3465-3670 \mathrm{~cm}^{-1}$ region $^{37}$, were clearly distinguished in the FTIR spectra. Although gibbsite and bayerite were identified in the XRD pattern of the $10 \mathrm{wt} \%$ CAC blended paste, these phases were not clearly identified by the FTIR tests since the corresponding strong signals did not appear at the 3475,3530 and $3630 \mathrm{~cm}^{-1}$ wavenumbers, which are characteristic of $\mathrm{O}-\mathrm{H}$ stretching vibrations. As denoted by the low intensity of the signals attributed to $\mathrm{AH}_{3}$ on the thermogravimetric curves (Fig. 5), this indicatesthat only small amounts of this compound were formed. The lack of strong signals within the 3450 to $3670 \mathrm{~cm}^{-1}$ rangealso corroborated the absence of significant amounts of $\mathrm{Ca}(\mathrm{OH})_{2}$ or portlandite in the selected pastes. Although these bands would be associated with others arising due to $\mathrm{O}-\mathrm{H}$ bending vibration, which appeared at $1027 \mathrm{~cm}^{-1}$ and within the 990 $970 \mathrm{~cm}^{-1}$ range, these lower frequency bands overlapped that of the newly formed aluminosilicate ge $\mathrm{e}^{20,27,30,31}$, which made it difficult to identify them. The presence of zeolitic-type 
products, which were distinguished only in the XRD spectra of the pastes that contained $20 \mathrm{wt} \%$ CAC, was associated with the absorption within the $660-720 \mathrm{~cm}^{-1}$ range $^{38,39}$. Conversely, the signals attributed to carbonates appeared from 1400 to $1500 \mathrm{~cm}^{-1}$ in the FTIR spectra. While calcite, whose existence was revealed in the XRD pattern of the CSW/PC blended pastes, was associated with the band that arose at $1420 \mathrm{~cm}^{-1}$, the signals attributed to other carbonate species, such as natron $\left(\mathrm{Na}_{2} \mathrm{CO}_{3} 10 \mathrm{H}_{2} \mathrm{O}\right)$, distinguished by $\mathrm{XRD}$ in the CSW pastes that contaiedCa $(\mathrm{OH})_{2}$ or $\mathrm{CAC}$, shifted to a higher wavenumber $\left(1455-1484 \mathrm{~cm}^{-1}\right)^{20}$. The absorption bands that arose at 712 and $875 \mathrm{~cm}^{-1}$, when appearing together with the band centered at about $1450 \mathrm{~cm}^{-1}$, were also linked to carbonate salts ${ }^{30}$.

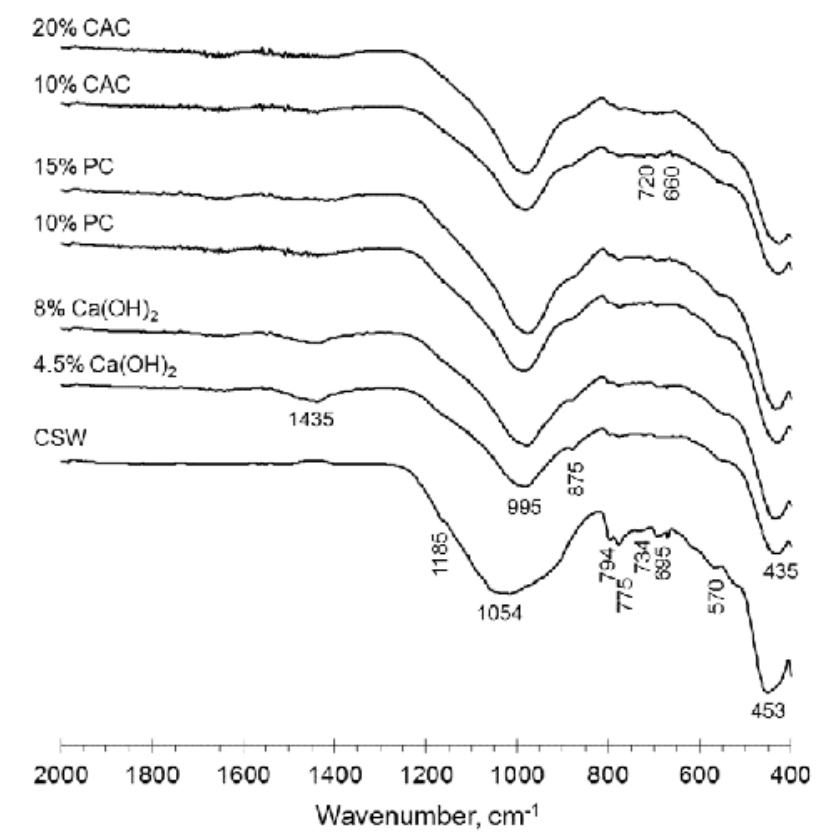

Fig. 6.FTIR spectra for the alkali-activated CSW pastes.

\subsection{Scanning electron microscopy (SEM)}

The SEM micrographs of fractured surfaces of alkali-activated CSW pastes, blended with 8 wt $\%$ $\mathrm{Ca}(\mathrm{OH})_{2}, 15 \mathrm{wt} \% \mathrm{PC}$ and $20 \mathrm{wt} \% \mathrm{CAC}$, are shown in Figures $7 \mathrm{a}$ and $7 \mathrm{~b}$, respectively. The ceramic sanitary-ware waste unreacted particles surrounded by an amorphous structure and covered by hydration products were observed by in SEM analyses. This corroborates the XRD and FTIR results, and indicates that CSW reacted only partially and was not totally consumed during the activation process. Zeolitic crystalline phases, previously identified in the XRD 
pattern of the $20 \mathrm{wt} \% \mathrm{CSW} / \mathrm{CAC}$ blended paste, were also distinguished from the microscopic analyses. Faujasite particles presented an octahedral morphology with regular crystal edges and a diameter close to $2 \mathrm{~m}^{40}$, and the zeolite A crystalline structures had a crosslinked layerlike morphology (similar to pseudo-herschelite crystals ${ }^{41}$ ).
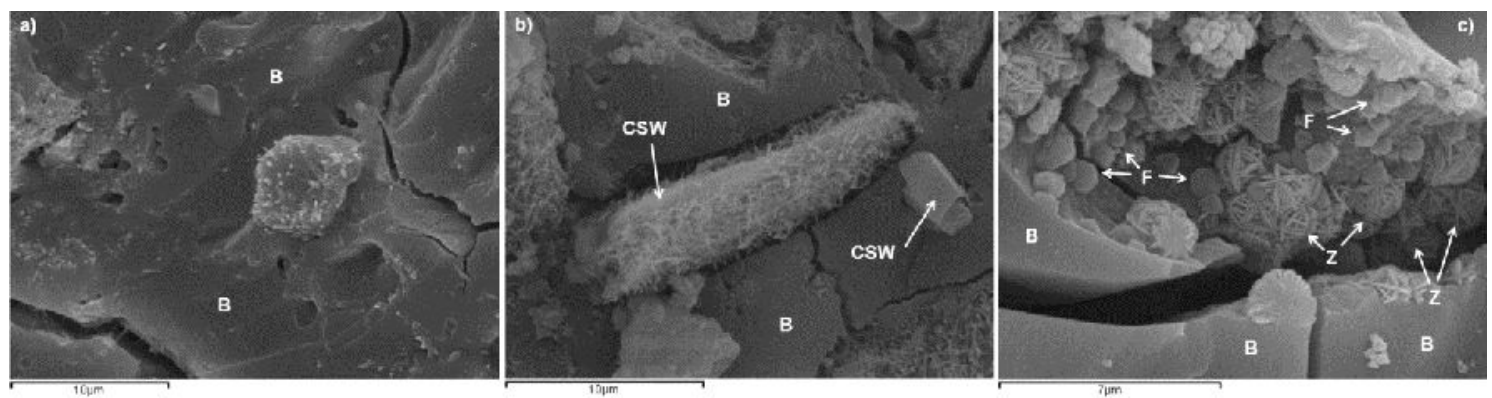

Fig. 7. SEM micrographs of pastes' fractured surfaces: a) $8 \% \mathrm{Ca}(\mathrm{OH})_{2}$; b) $15 \% \mathrm{PC}$; c) $20 \% \mathrm{CAC}$. B, binding gel; CSW, unreacted ceramic sanitary-ware waste particles; F, Faujasite; Z, Zeolite A.

\section{CONCLUSIONS}

The influence of different amounts and sources of calcium (CAC, $\mathrm{PC}$ and $\left.\mathrm{Ca}(\mathrm{OH})_{2}\right)$ on the microstructure and mechanical properties of an alternative cementitious system, developed by the alkali activation of ceramic sanitary-ware waste (CSW), has been assessed. The following conclusions are made according to the results of this paper:

- The different calcium sources seriously limited the compactability of the prepared mortars so that, while maximum amounts of $8 \mathrm{wt} \% \mathrm{Ca}(\mathrm{OH})_{2}$ and $15 \mathrm{wt} \% \mathrm{PC}$ could be used, no limit was observed in the CAC blended mortars for the selected activating solution used in the study.

- Mechanical properties significantly improved with the addition of calcium. While $40.06 \mathrm{MPa}$ and $64.41 \mathrm{MPa}$ were obtained in mortars prepared with $6 \mathrm{wt} \% \mathrm{Ca}(\mathrm{OH})_{2}$ and $10 \mathrm{wt} \% \mathrm{PC}$ respectively, 56.65 $\mathrm{MPa}$ and $70.69 \mathrm{MPa}$ were achieved in those containing 10 and $15 \mathrm{wt} \%$ CAC respectively (all of them cured at $65^{\circ} \mathrm{C}$ for 7 days).

- The hydration of CAC and PC in alkali-activated systems differed from that usually observed in water. Whereas neither portlandite nor ettringite was formed in CSW/PC 
blended pastes, only $\mathrm{AH}_{3}$ and small amounts of $\mathrm{C}_{3} \mathrm{AH}_{6}$ (distinguished only by $\mathrm{TG}$ analyses) were identified in those containing CAC. Ca from $\mathrm{Ca}(\mathrm{OH})_{2}$ and $\mathrm{Al}$ and $\mathrm{Ca}$ from $\mathrm{PC}$ and $\mathrm{CAC}$ were taken up in the newly-formed gel to confer $(\mathrm{N}, \mathrm{C})-\mathrm{A}-\mathrm{S}-\mathrm{H}$ or C-A-S-H gels, depending on the blend proportions.

\section{ACKNOWLEDGMENTS}

The authors are grateful to the Spanish Ministry of Science and Innovation for supporting this study through Projects GEOCEDEM BIA 2011-26947 and APLIGEO BIA2015-70107-R, Electron Microscopy Service of the UniversitatPolitècnica de València, and FEDER funding.

\section{REFERENCES}

1. Pacheco-Torgal F. Introduction to Handbook of Alkali-activated Cements, Mortars and Concretes. In: Pacheco-Torgal F, Labrincha J, Leonelli C, Palomo A, Chindaprasit P, eds. Chapter 1 in Handbook of Alkali-Activated Cements, Mortars and Concretes. Woodhead Publishing; 1st edition, United Kingdom, 2014: 1-18.

2. García-Lodeiro I, Palomo A, Fernández-Jiménez A. An overview of the chemistry of alkaliactivated cement-based binders. In: Pacheco-Torgal F, Labrincha J, Leonelli C, Palomo A, Chindaprasit P, eds. Handbook of Alkali-Activated Cements, Mortars and Concretes. Woodhead Publishing; 1st edition, United Kingdom, 2014: 19-47.

3. Payá J, Monzó J, Borrachero MV, Tashima MM. Reuse of aluminosilicate industrial waste materials in the production of alkali-activated concrete binders In: Pacheco-Torgal F, Labrincha J, Leonelli C, Palomo A, Chindaprasit P, eds. Handbook of Alkali-Activated Cements, Mortars and Concretes. Woodhead Publishing; 1st edition, United Kingdom, 2014: 487-514.

4. Shi C, Fernández-Jiménez A, Palomo A. New cements for the 21st century: The pursuit of an alternative to Portland cement. CemConcr Res. 2011;41:750-763.

5. Halicka A, Ogrodnik P, ZegardloB. Using ceramic sanitary ware waste as concrete aggregate.Constr Build Mater. 2013;48:295-305.

6. Baraldi L. World sanitaryware production and exports. Ceram World Rev. 2015;114:56-65. 
7. Medina C, Sánchez-Rojas MI, Frías M. Reuse of sanitary ceramic wastes as coarse aggregate in eco-efficient concretes. CemConcrCompos. 2012;34:48-54.

8. Medina C, Frías M, Sánchez-Rojas MI. Microstructure and properties of recycled concretes using ceramic sanitary ware industry waste as coarse aggregate. Constr Build Mater. 2012;31:112-118.

9. Guerra I, Vivar I, Llamas B, Juan A, Moran J. Eco-efficient concretes: The effects of using recycled ceramic material from sanitary installations on the mechanical properties of concrete. Waste Manag. 2009;29:643-646.

10. Pacheco-Torgal P, Jalali S. Reusing ceramic wastes in concrete. Constr Build Mater. 2010;24:832-838.

11. Alves AV, Vieira TF, de Brito J, Correia JR. Mechanical properties of structural concrete with fine recycled ceramic aggregates. Constr Build Mater. 2014;64:103-113.

12. Medina C, Banfill PFG, Sánchez-Rojas MI, Frías M. Rheological and calorimetric behaviour of cements blended with containing ceramic sanitary ware and construction/demolition waste. Constr Build Mater. 2013;40:822-831.

13. Reig L, Borrachero MV, Monzó J, Savastano H, Tashima MM, Payá J. Use of Ceramic Sanitaryware as an Alternative for the Development of New Sustainable Binders. Key Eng Mater.2016;668:172-180.

14. Reig L, Soriano L, Borrachero MV, Monzó J, Payá, J. A new binder from the alkali activation of ceramic sanitary-ware waste. In: Proceedings of the 34th Annual Cement and Concrete Science Conference, and Workshop on Waste Cementation, Sheffield, United Kingdom; 2014: 291-294.

15. Reig L, Soriano L, Borrachero MV, Monzó J, Payá J. Influence of calcium aluminate cement (CAC) on alkaline activation of red clay brick waste (RCBW). CemConcr Compos. 2016;65:177185.

16. Arbi K, Palomo A, Fernández-Jiménez A. Alkali-activated blends of calcium aluminate cement and slag/diatomite. Ceram Int. 2013;39:9237-9245.

17. García-Lodeiro I, Fernández-Jiménez A, Palomo A. Variation in hybrid cements over time. Alkaline activation of fly ash-portland cement blends. CemConcr Res. 2013;52:112-122. 
18. Reig L, Tashima MM, Soriano L, Borrachero MV, Monzó J, Payá J. Alkaline Activation of Ceramic Waste Materials. Waste Biom Val. 2013;4:729-736.

19. Reig L, Soriano L, Borrachero MV, Monzó J, Payá J. Influence of the activator concentration and calcium hydroxide addition on the properties of alkali-activated porcelain stoneware. ConstrBuild Mater.2014;63:214-222.

20. Pastor C, Fernández-Jiménez A, Vázquez T, Palomo A. Hidratación del cemento de aluminato de calcio en condiciones de muy elevada alcalinidad. Mater Construcc. 2009;59:2134.

21. Reig L, Tashima MM, Borrachero MV, Monzó J, Cheeseman CR, Payá J. Properties and microstructure of alkali-activated red clay brick waste. Constr Build Mater. 2013;43:98-106. 22. Garcia-Lodeiro I, Carcelen-Taboada V, Fernández-Jiménez A, Palomo A. Manufacture of hybrid cements with fly ash and bottom ash from a municipal solid waste incinerator. Constr Build Mater. 2016;105:218-226.

23. Fernández-Jiménez A, Palomo A, Vazquez T, Vallepu R, Terai T, Ikeda K. Alkaline activation of blends of metakaolin and calcium aluminate. J Am Ceram Soc.2008;91:12311236.

24. Criado M, Fernández-Jiménez A, Palomo A. Alkali activation of fly ash: Effect of the SiO2/Na2O ratio. Part I: FTIR study. Microporous Mesoporous Mater. 2007;106:180-191.

25. Fernández-Jiménez A, Vázquez T, Palomo A. Effect of sodium silicate on calcium aluminate cement hydration in highly alkaline media: A microstructural characterization. J Am Ceram Soc. 2011;94:1297-1303. 26. Bernal SA, de Gutierrez RM, Provis JL, Rose V. Effect of silicate modulus and metakaolin incorporation on the carbonation of alkali silicate-activated slags. CemConcr Res. 2010;40:898-907.

27. Pacewska B, Nowacka M, Antonovič V, Aleknevičius M. Investigation of early hydration of high aluminate cement-based binder at different ambient temperatures. $J$ Therm Anal Calorim.2012;109:717-726.

28. Mas MA, Monzó J, Payá J, Reig L, BorracheroMV.Ceramic tiles waste as replacement material in Portland cement. AdvCem Res. 2016;28:221-232. 
29. Hidalgo A, García JL, Alonso MC, Fernández L, Andrade C. Microstructure development in mixes of calcium aluminate cement with silica fume or fly ash. $J$ Therm Anal Calorim.2009;96:335-345.

30. Pacewska B, Wilińska I, Nowacka M. Studies on the influence of different fly ashes and Portland cement on early hydration of calcium aluminate cement. $J$ Therm Anal Calorim.2011;106:859-868.

31. Fernández-Carrasco L, Vázquez E. Reactions of fly ash with calcium aluminate cement and calcium sulphate. Fuel 2009;88:1533-1538.

32. Fernández-Carrasco L, Torréns-Martín D, Martínez-Ramírez S. Carbonation of ternary building cementing materials. CemConcr Compos. 2012;34:1180-1186.

33. García-Lodeiro I, Macphee DE, Palomo A, Fernández-Jiménez A. Effect of alkalis on fresh C-S-H gels. FTIR analysis. CemConcr Res. 2009;39:147-153.

34. LavatAE, Trezza MA, Poggi M. Characterization of ceramic roof tile wastes as pozzolanic admixture. WasteManag. 2009;29:1666-1674.

35. Garcia-Lodeiro I, Palomo A, Fernández-Jiménez A, Macphee DE. Compatibility studies between N-A-S-H and C-A-S-H gels. Study in the ternary diagram Na2O-CaO-Al2O3-SiO2H2O. CemConcr Res.2011;41:923-931.

36. García-Lodeiro I, Fernández-Jiménez A, Palomo A, Macphee DE. Effect of Calcium Additions on N-A-S-H Cementitious Gels.J Am Ceram Soc. 2010;93:1934-1940.

37. Fernández-Carrasco L, Vázquez T. Aplicación de la espectroscopia infrarroja al estudio de cemento aluminoso. Mater Construcc. 1996;46:39-51.

38. Rees CA, Provis JL, Lukey GC, van Deventer JSJ. Attenuated total reflectance Fourier transform infrared analysis of fly ash geopolymer gel aging.Langmuir 2007;23:8170-8179. 39. Granizo ML, Alonso S, Blanco-Varela MT, Palomo A. Alkaline Activation of Metakaolin : Effect of Calcium Hydroxide in the Products of Reaction. J Am Ceram Soc. 2002;85:225-231. 40. Liu Y, Yan C, Qiu X, Li D, Wang H, Alshameri A. Preparation of faujasite rock from fly ashbased geopolymer via in-situ hydrothermal method.J. Taiwan Inst Chem Eng. 2015:1-7. 41. Fernández-Jiménez A, Palomo A, Criado M. Alkali activated fly ash binders. A comparative study between sodium and potassium activators. Mater Construcc. 2006;56:51-65. 